\title{
Virulence of Pythium deliense causing soft rot in Ginger, a new report from Kerala, India
}

\author{
Vafa AL, Anju JV and Rajan PP
}

The Zamorin's Guruvayurappan College, Kozhikode, Kerala 673014, India

Vafa AL, Anju JV, Rajan PP 2021 - Virulence of Pythium deliense causing soft rot in ginger, a new report from Kerala, India. Studies in Fungi 6(1), 488-494, Doi 10.5943/sif/6/1/38

\begin{abstract}
Ginger (Zingiber officinale Rosc.) rhizome is widely used as a spice and medicine and, its large-scale production is being seriously affected by several fungal and bacterial diseases. Soft rot disease caused by various species of Pythium is the most destructive among them. Samples showing soft rot symptoms were collected from the ginger fields of Kozhikode and Wayanad districts of Kerala. Detailed study of the morphology, growth parameters and molecular characteristics of the fungal isolates confirmed the identity of Pythium deliense. The pathogenicity of the isolates was demonstrated by in vitro and in vivo methods. This is the first report of the pathogen, $P$. deliense causing soft rot in ginger from Kerala, India.
\end{abstract}

Keywords - isolation - pathogenicity - rhizome - spice - Zingiber officinale

\section{Introduction}

Ginger (Zingiber officinale Rosc. Zingiberaceae) is a perennial herb that is extensively used as a spice, herbal medicine and dietary adjunct that enhances the flavour and taste of foods. It has anti-inflammatory, antifungal, antiviral, antioxidant and anticancer properties (Naghsh 2015, Tohma et al. 2017, Ezzat et al. 2018, Hussein \& Joo 2018, Yusuf et al. 2018, Kaushik et al. 2020, Kharisma et al. 2020) and hence the rhizome is used as an inevitable ingredient in Ayurvedic, Unani and Chinese herbal medicines to treat several diseases. Considering the importance of the crop, it has been cultivated in many tropical and subtropical areas of the world. The main producers are India, China, Nigeria and Nepal (FAOSTAT 2019).

Diseases are the most important production constraint of the ginger crop (Kumar \& Hayward 2016). Apart from socio-economic problems, the main reasons for the decline in the productivity of ginger all over the world are biotic and abiotic stress issues. The main biotic threat faced by farmers is soft rot or rhizome rot disease caused by various species of Pythium. Dohroo (2005) described rhizome rot as the most destructive disease of ginger worldwide and estimated loss in a range of 50-90\%. He listed eleven species of Pythium as causal organisms of soft rot of ginger from different parts of the world and among them, Pythium aphanidermatum and P. myriotylum are the species reported as the most commonly associated pathogen with the disease.

It was reported that the continuous climatic shifts with temperature rise and the soil moisture diminution adversely affected the growth of many crops and many weak pathogens may come to light as aggressive pathogens (Subila \& Bhai 2020b). Considering the worldwide scenario, there are only a few reports available about Pythium deliense as a pathogen, compared to other pathogenic Pythium species. Meurs (1934) isolated Pythium from the tobacco plant and correctly identified and described it as $P$. deliense. In India, reports were available to cause rotting in tomato 
(Singh \& Srivastava 1953), mung bean (Ragunathan 1968), fish bean (Pandotra et al. 1971) and also in the rhizosphere and roots of black pepper (Subila \& Bhai 2020b). It was also reported from some other countries like Nicaragua (Drechsler 1957) from tobacco, Pakistan (Lodhi et al. 2004) from Piper betel, Thailand (Intaparn et al. 2019) from Catharanthus roseus, etc. But from Kerala, it was reported from Eucalyptus (Sharma et al. 1984) and black pepper (Subila \& Bhai 2020a).

The only report on the virulent effect of $P$. deliense in ginger soft rot was reported from India (Madhya Pradesh), by Haware \& Joshi (1974) and Jooju (2005). To our best knowledge, there were no reports available about $P$. deliense as a soft rot causing pathogen in ginger from Kerala to date. Hence this work is aimed for a detailed study on the disease-causing ability of $P$. deliense in ginger.

\section{Materials \& methods}

\section{Diseased sample collection and pathogen isolation}

From the ginger fields of Chakittappara and Vythiri areas of Kozhikode and Wayanad Districts, Kerala, three diseased ginger rhizome samples were collected (Fig. 1). The symptoms produced in infected ginger were noted in detail and documented. The samples were collected in polybags and brought into the plant pathology laboratory of The Zamorin's Guruvayurappan College, Kozhikode, Kerala for isolation of pathogen and identification. The rhizomes were washed thoroughly with tap water to remove the soil particles. Small cuts were made from the rot or lesion along with some healthy portions and the rhizome pieces were surface sterilized with $0.1 \% \mathrm{HgCl}_{2}$ for $1 \mathrm{~min}$ followed by washing in sterile distilled water three times. To remove adhered water completely from the surface of ginger pieces, they were kept on sterile blotting papers. It was then transferred onto pre-sterilized and solidified Potato Dextrose Agar (PDA) medium, in Petri plates. The plates with samples were incubated at room temperature $\left(25 \pm 2^{\circ} \mathrm{C}\right)$ for two days. The fungal outgrowth, from actively growing edges of hyphal tips, were transferred onto PDA slants and maintained for further studies. The fungal cultures thus grown from the specimen were subcultured in PDA slants frequently to maintain the purity of the culture. All the cultures obtained are deposited at the ZGC herbarium, India. The facesoffungi number was registered as mentioned in Jayasiri et al. (2015).
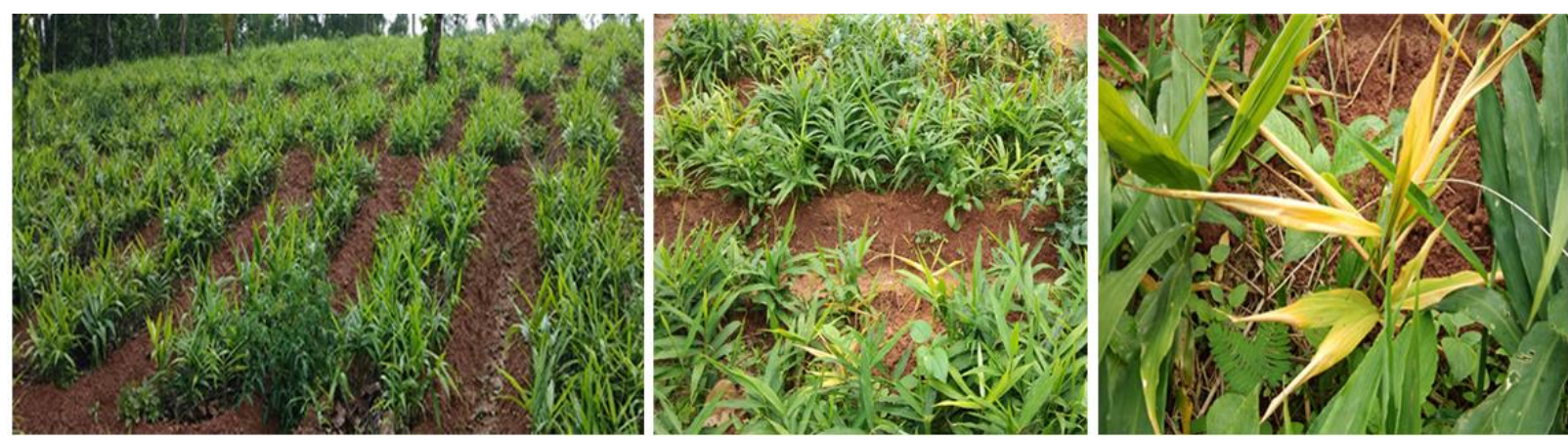

Fig. 1 - Disease symptoms in the field.

\section{Identification of the pathogen}

Different media were tested to evaluate the sporulation of pathogen and also to identify the pathogen at the species level. Culture discs $(5 \mathrm{~mm}$ size) were collected from the actively growing edges of culture and were inoculated at the centre of the $90 \mathrm{~mm}$ Petri plates containing media like potato dextrose agar (PDA) and Corn Meal Agar (CMA). These plates were then incubated for $96 \mathrm{~h}$ at room temperature. The growth rate of the isolates was measured at a $24 \mathrm{~h}$ interval and documented the colony morphology. The fungal hyphae taken onto glass slides under sterile conditions were stained with lactophenol cotton blue for microscopical observations. The microphotographs and measurements of fungal structures were taken using Magnus MX21 $i \mathrm{LED}$ 
(Microscope) Magcam-DC14 (Camera). They were compared with the details in the monograph of the genus Pythium (Plaats-Niterink 1981).

\section{Production of Oospores}

Oogonia and its structures are being used to characterize and identify various species of Pythium. For oogonia production in nutrient media, $5 \mathrm{~mm}$ mycelial plugs (disc with mycelia) were collected from the actively growing margins of $72 \mathrm{~h}$ old culture. The culture discs were kept in sterile distilled water along with sterile leaf blades of Brachiaria ruziziensis and incubated under humid conditions, to induce oogonia production. The oogonia production was observed under the microscope and documented all the characters as their size and structures.

\section{Sporangial morphology}

Sporangial characters are another important parameter widely used for Pythium species identification. The sporangial morphology was studied using the slide culture technique. Fungal culture disc ( $3 \mathrm{~mm}$ size) collected from an actively growing margin of $72 \mathrm{~h}$ old culture and placed on a sterile microscopic glass slide with an agar block. The microscopic glass slide with culture block was incubated in a humid chamber at $25 \pm 1^{\circ} \mathrm{C}$ for 3 days. The slide was fixed with lactophenol cotton blue for staining the culture and a coverslip was placed over the agar block and observed under a microscope for sporangia.

\section{Molecular characterization}

Though the preliminary identification of the isolates was done based on morphological characteristics, identity was confirmed using sequences of the internal transcribed spacer region of the ribosomal DNA (ITS rDNA) as described by White et al. (1990). About $100 \mathrm{mg}$ of the tissue/mycelium was homogenized using liquid nitrogen and the powdered tissue was transferred to a microcentrifuge tube. DNA was extracted using a kit (NucleoSpin ${ }^{\circledR}$ Plant II Kit). The ITS rDNA region of the isolates was amplified using universal primers ITS1 $\left(5^{0}\right.$ TCCGTAGGTGAACCTGCGG- $3^{0}$ ) and ITS4 $\left(5^{0}\right.$-TCCTCCGCTTATTGATATGC- $3^{0}$ ). The PCR product was purified using ExoSAP-IT treatment. Sequencing was done using the BigDye Terminator v3.1 method. The sequences then aligned and were compared with the related Pythium sequences deposited at the National Center for Biotechnology Information (NCBI) using BLAST search.

\section{Evaluation of pathogenicity of the isolates}

The three Pythium isolates obtained were tested to prove Koch's Postulates (Pathogenicity) by in vitro and in vivo methods. To prove pathogenicity by in vitro method, healthy and mature seedlings of ginger were collected and washed with $70 \%$ ethyl alcohol followed by sterile distilled water. The seedlings were incubated in sterile plastic boxes containing wet filter paper and moistened cotton. For each isolate and also for the control, three seedlings were used. A small pinprick was made at the base of each seedling using a sterile needle and an agar disc (Pythium culture) collected from the margin of actively growing fungal isolate was placed on the pricked area, in a way that the fungal mycelia are in contact with pin-prick. Seedlings with agar disc, without pathogen, were placed on pricked regions and maintained as control. The humidity inside the inoculation box was maintained by placing wet absorbent cotton and with frequent wetting. The box was incubated at room temperature for five days. The part of the rhizome of seedling which showed the infection was cut along with the healthy part and reisolated the pathogen by using PDA medium, as mentioned earlier.

For in vivo evaluation on pathogenicity, the ginger seedlings were raised in earthen pots filled with a potting mixture containing soil, sand and farmyard manure (2:1:1) and grown under greenhouse conditions. The isolates of Pythium were subcultured onto PD (Potato Dextrose) broth using mycelial plugs $(5 \mathrm{~mm})$ taken from the advancing margin of five days old pure culture of each isolate. Ten days old suspension culture of Pythium grown on PD broth was used for pathogenicity 
tests. To prepare the inoculum for testing, the suspension culture, raised in a $250 \mathrm{ml}$ conical flask was homogenized in a mixer grinder, made up to $1000 \mathrm{ml}$. The fungal suspension was inoculated to the soil, in pots with two months old ginger seedlings $(50 \mathrm{ml} / \mathrm{pot})$. The soil around the plant was mixed with culture suspension thoroughly for uniform distribution of pathogen in soil. The plants without inoculum served as control. For each isolate and control, three replications were maintained. After the incorporation of culture into the base of seedlings, the plants were irrigated regularly to maintain good moisture and humidity. Regular observations were made for the appearance and development of symptoms. The part of the rhizome which showed the infection was cut along with the healthy part and inoculated onto pre-sterilized PDA for reisolation of the pathogen as mentioned earlier.

\section{Results}

\section{Collection, isolation and identification of the pathogen}

Infected ginger samples showed marginal yellowing of the leaves, except for the midrib portion. Some pseudostems were drooped (Fig. 1). The rhizomes were partially rotten, showing signs of soft rot infections. After the $24 \mathrm{~h}$ incubation period as mentioned earlier, the plated ginger pieces began growing mycelium radially from the infected rhizome pieces.

Identification of Pythium isolates has been done based on morphological and molecular characteristics. The different isolates of Pythium grown on PDA and CMA exhibited different growth rates (av. $34.3 \mathrm{~mm}$ on PDA and $36.7 \mathrm{~mm}$ on CMA) but have floral cottony type colony morphology (Fig. 2a). The sizes of the main hyphae were 7-9 $\mu \mathrm{m}$. Sporangia were observed as filamentous inflated or torulated structures with swollen side branches and mostly terminal (Fig. 2c). The encysted zoospores were $8-12 \mu \mathrm{m}$ in diameter. The production of oogonia was observed in isolates after $48 \mathrm{~h}$ by the grass leaf method. They were smooth, terminal and globose, 16-24 $\mu \mathrm{m}$ (av. $19.7 \mu \mathrm{m}$ ) in diameter. These characters showed close similarity with $P$. aphanidermatum but the bending of oogonial stalks towards the antheridia was the unique character of $P$. deliense (Fig. 2b). Antheridia monoclinous, broad, apical and/or intercalary (6.2-8.3 $\mu \mathrm{m}$ length). Oospores were highly aplerotic, 15-19 $\mu \mathrm{m}$ (av. $16.3 \mu \mathrm{m})$ diameter and wall thickness were up to $2 \mu \mathrm{m}$. The identity of Pythium isolates was further confirmed molecularly. Amplicons of the expected size were sequenced and a BLAST search gives the closest similarity with $P$. deliense having 100\% resemblance. The culture was registered and obtained the Facesoffungi number (FoF10628).
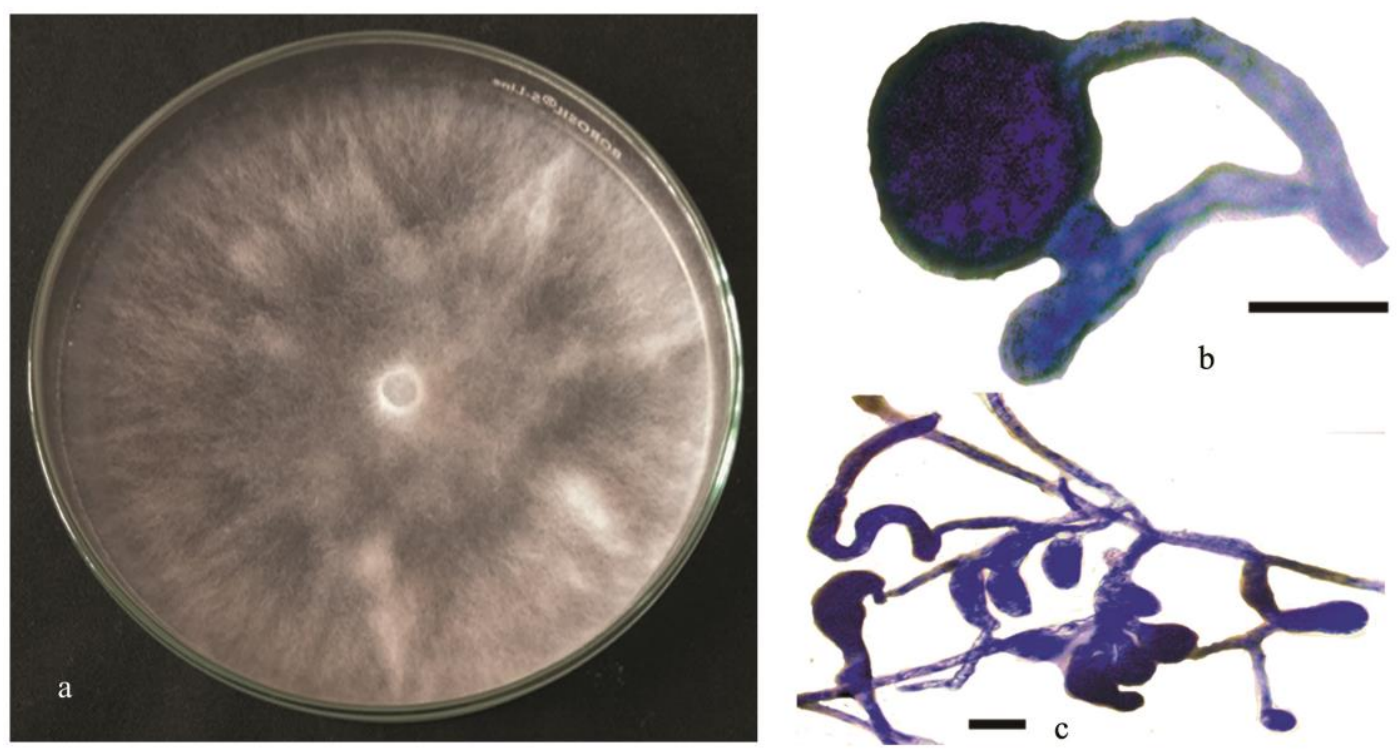

Fig. 2 - Morphology of the pathogen. a Colony morphology on PDA. b Oogonium and antheridium. c Sporangia. Scale bars: b-c $=10 \mu \mathrm{m}$. 


\section{Pathogenicity of the isolates}

Pathogenicity of the different isolates of $P$. deliense was proved under both in vitro and in vivo conditions. Inoculation with $P$. deliense on ginger rhizomes developed symptoms after $48 \mathrm{~h}$ of incubation as brownish spots. The size of the lesion increased further after $96 \mathrm{~h}$. The rhizome pieces along with a region of the dark coloured lesion were incised, cleaned, surface sterilized and inoculated onto PDA. White floral cottony mycelia were found to grow after $24 \mathrm{~h}$ of incubation showed the highest similarity and characteristics of the fungus Pythium which was fulfilling Koch's postulates (Fig. 3c-d).

On inoculating the plants with $P$. deliense under greenhouse conditions, symptoms such as foliar yellowing at the tip of the lower leaves started to appear within 5 days. It progressed along the margins of the leaves except for the midrib portion and after 15 days of inoculation, yellowing appeared on the upper leaves also. When the plants were uprooted, slight rotting of the rhizomes was observed. The pathogen was re-isolated and proved Koch's postulates (Fig. 3a-b).
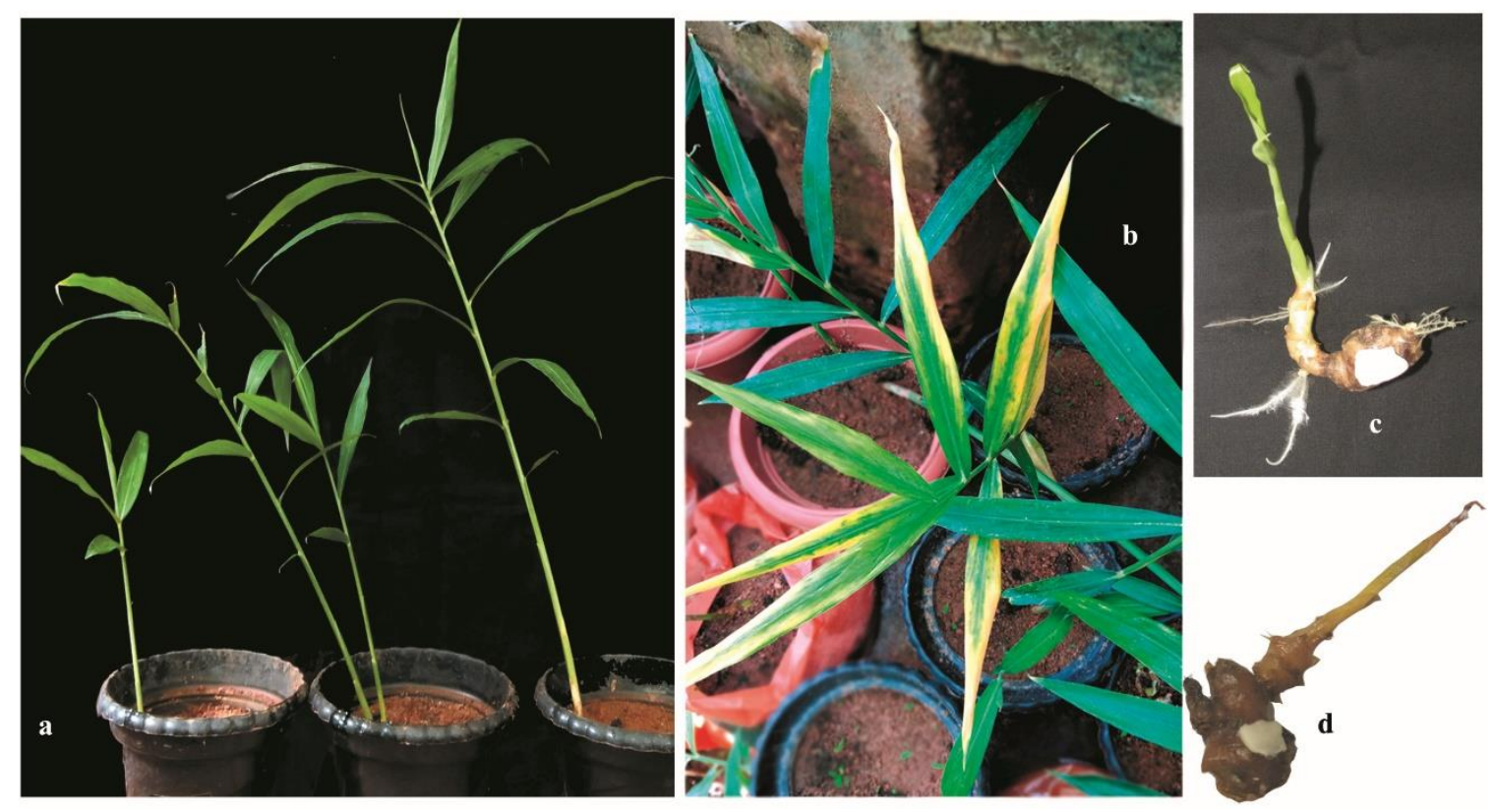

Fig. 3 - Pathogenicity assay. a in vivo study controls. b in vivo study test. c in vitro study control. $\mathrm{d}$ in vitro study test.

\section{Discussion}

Rhizome rot caused by Pythium spp. is the most destructive disease of ginger resulting in heavy crop loss all over the world, wherever ginger is being grown (Dohroo 2005, Stirling et al. 2009, Chattopadhya 1997). Le et al. (2014) reported that about 15 Pythium species have been confirmed as pathogens that cause soft rot disease in ginger all over the world. In India, Pythium spp. causing soft rot disease in ginger was first reported long back, around 100 years ago (Butler 1907), from Surat (Gujrat) and it was identified as P. gracile. Thereafter, many other Pythium spp. affecting ginger has been recorded. Among them, there were only two reports (Haware \& Joshi 1974, Jooju 2005), stating that $P$. deliense as soft rot causing pathogen in ginger. As mentioned earlier, there are many research findings, supported the pathogenicity of $P$. deliense as the soft rot pathogen in many crops, but soft rot incidence in ginger due to $P$. deliense was not reported from Kerala, hence, this is the first report. Moreover, the pathogen character shares its identity with the isolates reported by previous workers (Drechsler 1957, Lodhi et al. 2004).

As we understood, $P$. deliense is mainly a soil borne fungus and a water loving pathogen. The pathogen gets multiplied under high humid conditions during the rainy season and cause rotting on juvenile roots of ginger cause root rot. The rotting progress from roots and ultimately result in rotting on the rhizome. The infected rhizomes become brownish discolouration and infected tissues 
become macerated. From the infected rhizome, the pseudostem comes off easily. As the already documented soft rot symptoms in ginger due to various species of Pythium, the symptoms due to $P$. deliense is also found the same with yellowing of leaves, progress from lower to upper leaves and ultimately the infected plants get toppled off. The rapid spread of infection in the fields under low drainage and with water stagnated conditions.

The morphological characteristics, pathogenicity studies and molecular characteristics confirmed the identity of $P$. deliense, a pathogenic species that causes soft rot in ginger in Kerala. The present study and identification of pathogen revealed the importance of Pythium deliense as a virulent pathogen, associated with soft rot disease in Zingiber officinale Rosc. in Kerala.

\section{Acknowledgements}

The first author expresses her sincere gratitude towards UGC for financial support.

\section{References}

Butler EJ. 1907 - An account of genus Pythium and some Chytridiaceae. Memoirs of the department of agriculture in India. Botanical series 1, 1-162.

Chattopadhya SB. 1997 - Disease of plants yielding drugs, dyes and spices. New Delhi: Indian Council of Agricultural Research, India. 35-42.

Dohroo NP. 2005 - Diseases of ginger. In: Ravindran PN, Nirmal Babu K (eds), Ginger, the genus Zingiber. CRC Press, Boca Raton, pp. 305-340.

Drechsler C. 1957 - A Pythium causing stem rot of tobacco in Nicaragua and Indonesia. Sydowia $14,1-6$.

Ezzat SM, Ezzat MI, Okba MM, Menze ET, Abdel-Naim AB. 2018 - The hidden mechanism beyond ginger (Zingiber officinale Rosc.) potent in vivo and in vitro anti-inflammatory activity. Journal of ethnopharmacology 214, 113-123.

FAOSTAT. 2019 - Food and Agriculture Organization of the United Nations Statistics. http://faostat.fao.org/site/339/default.aspx. (Accessed on August 3, 2021).

Haware MP, Joshi LK. 1974 - Yellow disease of ginger (Zingiber officinale) from Madhya Pradesh. Indian phytopathology 27, 158-161.

Hussein KA, Joo JH. 2018 - Antifungal activity and chemical composition of ginger essential oil against ginseng pathogenic fungi. Current Research Environmental Applied Mycology 8, 194-203.

Intaparn P, Noireung P, Maumoon R, McGovern RJ et al. 2019 - First report of Pythium deliense causing root and crown rot on Catharanthus roseus in Thailand. Plant Pathology \& Quarantine 91, 239-247.

Jayasiri SC, Hyde KD, Ariyawansa HA, Bhat J et al. 2015 - The Faces of Fungi database: fungal names linked with morphology, phylogeny and human impacts. Fungal Diversity 74(1), 3-18. Doi 10.1007/s13225-015-0351-8

Jooju B. 2005 - Evaluation of genetic diversity of Pythium spp. causing soft rot of ginger using phenotypic and molecular methods (Doctoral dissertation, MPhil Thesis, Bharathidasan University, Thiruchirapalli).

Kaushik S, Jangra G, Kundu V, Yadav JP, Kaushik S. 2020 - Anti-viral activity of Zingiber officinale (Ginger) ingredients against the Chikungunya virus. Virus disease 31 (3), 270-276.

Kharisma VD, Ansori ANM, Nugraha AP. 2020 - Computational study of ginger (Zingiber officinale) as E6 inhibitor in human papillomavirus type 16 (HPV-16) infection. Biochemical Cellular Archives 20 (1), 3155-3159.

Kumar A, Hayward AC. 2016 - Bacterial diseases of ginger and their control. In Ginger, CRC press. pp. 361-386.

Le DP, Smith M, Hudler GW, Aitken E. 2014 - Pythium soft rot of Ginger: Detection and identification of causal pathogens and their control. Crop Protection 65, 153-167. 
Lodhi AM, Shahzad S, Ghaffar A. 2004 - Pythium deliense, a new record from Pakistan. Pakistan Journal of Botany 36, 673-676.

Meurs A. 1934 - Parasitic stemburn of Deli Tobacco. Phytopathologische Zeitschrift 7, 169-185.

Naghsh F. 2015 - Nano drug delivery study of anticancer properties on ginger using QM/MM methods. Oriental Journal of chemistry 31, 465-478.

Pandotra VR, Gupta JH, Sastry KSM. 1971 - Occurrence of wilt and stem burn of Tephrosia vogelii in India. Current Science 40, 442-443.

Plaats-Niterink J Van Der. 1981 - Monograph of the genus Pythium. Studies in Mycology. No.21. Centraalbureau voor Schimmelcultures, Baarn. pp. 1-242.

Ragunathan V. 1968 - Damping-off of green gram, cauliflower, daincha, ragi and cluster bean. Indian phytopathology 21, 456-457.

Sharma JK, Mohanan C, Maria Florence EJ. 1984 - Nursery diseases of Eucalyptus in Kerala. European Journal of Forest Pathology 14, 77-89.

Singh B, Srivastava HC. 1953 - Damping-off of tomato seedlings. Journal of Indian Botanical Society $32,1-16$.

Stirling GR, Turaganivalu U, Stirling AM, Lomavatu MF, Smith MK. 2009 - Rhizome rot of ginger (Zingiber officinale) caused by Pythium myriotylum in Fiji and Australia. Australasian Plant Pathology 38, 453-460.

Subila KP, Suseela Bhai R. 2020a - Pythium deliense, a pathogen causing yellowing and wilt of black pepper in India. New Disease Reports 42, 6.

Subila KP, Susheela Bhai R. 2020b - Documentation of Pythium species from the rhizosphere and roots of yellowing affected black pepper (Piper nigrum L.) vines. International Journal of Multidisciplinary Educational Research 92, 201-217.

Tohma H, Gülçin İ, Bursal E, Gören AC et al. 2017 - Antioxidant activity and phenolic compounds of ginger (Zingiber officinale Rosc.) determined by HPLC-MS/MS. Journal of food measurement and characterization 11 (2), 556-566.

Yusuf A, Lawal B, Abubakar AN, Berinyuy E et al. 2018 - In-vitro antioxidants, antimicrobial and toxicological evaluation of Nigerian Zingiber officinale. Clinical Phytoscience, 4-12.

White TJ, Bruns T, Lee S, Taylor J. 1990 - Amplification and direct sequencing of fungal ribosomal RNA genes for phylogenetics. In: Innis MA, Gelfand DH, Sninsky JJ, White TJ (eds), PCR protocols: a guide to methods and applications. Academic Press, New York, pp. 315-322. 